\title{
The effects of simvastatin on cellular viability, stemness and osteogenic differentiation using 3-dimensional cultures of stem cells and osteoblast-like cells
}

\author{
Hyunjin Lee ${ }^{A-F}$, Hyuna Lee ${ }^{A-F}$, Chae-Bin Na ${ }^{A-F}$, Jun-Beom Park ${ }^{A-F}$ \\ Department of Periodontics, College of Medicine, The Catholic University of Korea, Seoul, South Korea \\ A - research concept and design; $B$ - collection and/or assembly of data; $C$ - data analysis and interpretation; \\ $D$ - writing the article; $E$ - critical revision of the article; $F$ - final approval of the article
}

Address for correspondence

Jun-Beom Park

E-mail:jbassoonis@yahoo.co.kr

\section{Funding sources}

This research was supported by the Basic Science Research Program through the National Research Foundation of Korea (NRF), funded by the Ministry of Science, Information and Communication Technology \& Future Planning of South Korea (NRF-2017RTA1A1A05001307).

\section{Conflict of interest}

None declared

\section{Acknowledgements \\ The first 2 authors contributed equally to the study. The authors gratefully acknowledge the support provided by the Basic Science Research Program through the NRF, funded by the Ministry of Science, Information and Communication Technology \& Future Planning.}

Received on May 18, 2017

Reviewed on June 30, 2017

Accepted on August 9, 2018

Published online on February 5, 2019

\section{Cite as}

Lee H, Lee H, Na C-B, Park J-B. The effects of simvastatin on cellular viability, stemness and osteogenic differentiation using 3-dimensional cultures of stem cells and osteoblastlike cells. Adv Clin Exp Med. 2019;28(5):699-706. doi:10.17219/acem/94162

DOI

$10.17219 /$ acem $/ 94162$

\section{Copyright}

Copyright by Author(s)

This is an article distributed under the terms of the Creative Commons Attribution Non-Commercial License (http://creativecommons.org/licenses/by-nc-nd/4.0/)

\begin{abstract}
Background. Simvastatin has been reported to increase the therapeutic effects of many kinds of stem cells by increasing the number of those cells. However, the effects of simvastatin on the differentiation potential of stem cells have not been clearly determined.

Objectives. The aim of the study was to evaluate the effects simvastatin has on cellular viability, stemness and osteogenic differentiation using 3-dimensional cell spheroids of stem cells and osteoblast-like cells.

Material and methods. Three-dimensional cell spheroids were fabricated using concave silicon elastomerbased microwells in the presence of simvastatin at concentrations of $1 \mu \mathrm{M}$ and $10 \mu \mathrm{M}$. Qualitative cellular viability was determined with a confocal microscope, and quantitative cellular viability was evaluated using a cell-counting assay kit. The expression of stem cell surface markers was tested. A quantitative real-time polymerase chain reaction (qRT-PCR) was performed to evaluate the expression of collagen I and RUNx2. Alkaline phosphatase activity and alizarin red S staining were used to assess osteogenic differentiation.

Results. The spheroids formed well in the concave silicon elastomer-based microwells, and the application of simvastatin caused no significant morphological changes. No significant changes in cellular viability were noted with the addition of simvastatin on days 1,3 and 5 . Secretion of the vascular endothelial growth factor (VEGF) was observed on day 1 and remained stable throughout the culture period. Expression of the CD90 surface marker was seen on day 7. The addition of simvastatin caused a statistically significant increase in the expression of collagen I and RUNX2. It also caused decreases in alkaline phosphatase activity and alizarin red S staining.
\end{abstract}

Conclusions. The study clearly showed that the application of simvastatin enhanced collagen I and RUNX2 expression; however, this did not lead to increases in alkaline phosphatase activity or alizarin red $\mathrm{S}$ staining.

Key words: gingiva, simvastatin, stem cells, cell differentiation, cellular spheroids 
Simvastatin is a chemical modification of lovastatin, a rate-limiting enzyme of the cholesterol synthesis pathway. ${ }^{1,2}$ Simvastatin has been reported to promote osteoblastic activity and inhibit osteoclastic activity. ${ }^{3}$ Previous reports have shown that simvastatin positively affects the differentiation and mineralization of osteoprecursor cells through the estrogen receptor pathway by increasing estrogen receptor- $\alpha$ expression. ${ }^{4}$ A combination of simvastatin and bone morphogenetic protein-2 enhanced the differentiation of osteoprecursor cells through the bone morphogenetic protein pathway by enhancing $\mathrm{pSmad} 1 / 5 / 8$ expression. ${ }^{5}$

The effects of simvastatin on mesenchymal stem cells (MSCs) have been observed in previous studies. ${ }^{6-9}$ Simvastatin has been reported to increase the therapeutic effects of nucleus pulposus stem cells by increasing the number of those cells. ${ }^{8}$ It has also been shown to induce enhanced proliferation of cultured neural stem cells. ${ }^{7}$ Conversely, simvastatin has been reported to negatively modulate bone marrow MSC proliferation in a dose-dependent manner and to regulate the expression of proliferation-related genes. ${ }^{6}$ One report showed that simvastatin both directly interfered with the proliferation of stem cells and promoted cell death. ${ }^{9}$ Moreover, the effects of simvastatin on the differentiation potential of stem cells have not been clearly determined. Recently, 3-dimensional culture systems using stem cells have been applied to cell therapy. ${ }^{10}$ These stem-cell spheroids maintained the viability and stemcell characteristics of stem-cell surface-marker expression and differentiation potential. ${ }^{11}$ In a previous study, cell spheroids from gingival cells and osteoprecursor cells were shown to be a promising strategy for stem-cell therapy. ${ }^{12}$ The current study was therefore performed to evaluate the effects of simvastatin on cellular viability, stemness and osteogenic differentiation using 3-dimensional cell spheroids of stem cells and osteoblast-like cells.

\section{Material and methods}

\section{Formation of cell spheroids with human gingiva-derived stem cells and osteoblast-like cells}

Stem cell spheroids were formed in concave silicon elastomer-based microwells (StemFit 3D; Micro Fit Co. Ltd., Seongnam, South Korea) with a diameter of $600 \mu \mathrm{M}$. Gingiva-derived stem cells (GMSCs) and osteoblast-like cells (MC3T3-E1 cells; American Type Culture Collection, Manassas, USA) were plated in a 1:1 ratio $\left(5 \times 10^{5}\right.$ cells/well $)$, cultured in an alpha-minimal essential medium ( $\alpha$-MEM; Gibco, Grand Island, USA) with a total volume of $1.5 \mathrm{~mL}$, and then supplemented with $15 \%$ fetal bovine serum (Gibco), $100 \mathrm{U} / \mathrm{mL}$ of penicillin, $100 \mu \mathrm{g} / \mathrm{mL}$ of streptomycin (SigmaAldrich, St. Louis, USA), 200 mM of L-glutamine (Sigma-Aldrich), $10 \mathrm{mM}$ of ascorbic acid 2-phosphate (Sigma-Aldrich), $38 \mu \mathrm{g} / \mathrm{mL}$ of dexamethasone (Fujifilm Wako Pure Chemical
Corp., Osaka, Japan), and $2 \mathrm{mg} / \mathrm{mL}$ of glycerophosphate disodium salt hydrate (Sigma-Aldrich). The culturing was performed in the presence of simvastatin (Sigma-Aldrich) at concentrations of $0 \mu \mathrm{M}$ (the untreated control group), $1 \mu \mathrm{M}$ and $10 \mu \mathrm{M}$ with dimethyl sulfoxide (DMSO) used as a dissolving agent. The media were changed every second day. The GMSCs were obtained from the mandibular area of a healthy female participant undergoing second-stage implant surgery, using a previously reported method. ${ }^{13}$ The study design was reviewed and approved by the Institutional Review Board of Seoul St. Mary's Hospital (College of Medicine, Catholic University of Korea, Seoul, South Korea; approval No. KC11SISI0348), and informed consent was obtained from the patient. On days 1, 3 and 5, inverted microscopy (Olympus Corporation, Tokyo, Japan) was used to evaluate the morphology of the stem cells being tested.

\section{Determination of cell viability}

The viability of the spheroids was qualitatively analyzed by an assay using the Live/Dead Kit (Molecular Probes, Eugene, USA). The spheroids were washed twice with the growth media, followed by suspension in $2 \mathrm{~mL}$ of $\alpha$-MEM (containing $1 \mu \mathrm{L}$ of $4 \mathrm{mM}$ calcein acetoxymethyl ester working solution and $4 \mu \mathrm{L}$ of $2 \mathrm{mM}$ ethidium homodimer-1) for $30 \mathrm{~min}$ at room temperature. The spheroids stained with calcein acetoxymethyl ester and ethidium homodimer-1 were observed under a confocal laser microscope (LSM800 w/Airyscan; Carl Zeiss, Oberkochen, Germany) on days 3 and $5(\mathrm{n}=3)$.

Quantitative cell-viability analyses were performed on days 1, 3 and 5. Using a Dojindo Cell Counting Kit-8 (CCK-8; Dojindo Molecular Technologies, Tokyo, Japan), we added 2-(2-methoxy-4-nitrophenyl)-3-(4-nitrophenyl)5-(2,4-disulfophenyl)-2H tetrazolium monosodium salt (WST-8) to the cultures, and the spheres were incubated for $1 \mathrm{~h}$ at $37^{\circ} \mathrm{C}$. Viable cells were identified through the assay, which relies on the ability of mitochondrial dehydrogenases to oxidize WST-8 into a formazan product. The spectrophotometric absorbance of the samples was measured at $450 \mathrm{~nm}$ using a microplate reader (BioTek Instruments Inc., Winooski, USA) $(\mathrm{n}=3)$.

\section{Evaluation of the secretion of human VEGF for paracrine effects}

The 3-dimensional systems were used to determine the amount of human vascular endothelial growth factor (VEGF) on days 1, 3 and 5 using a commercially available enzyme-linked immunosorbent assay (ELISA) kit (Quantikine ELISA; R\&D Systems, Inc., Minneapolis, USA). All the reagents and samples were prepared according to the manufacturers' recommendations. The absorbance levels at $450 \mathrm{~nm}$ and $570 \mathrm{~nm}$ were measured, and the differences were used as the values for the paracrine effects $(n=2)$. 


\section{Evaluation of maintenance of stemness}

Approximately $1.5 \times 10^{5}$ GMSCs and $1.5 \times 10^{5}$ osteoblastlike cells were incubated with specific fluorescein isothiocyanate-conjugated mouse monoclonal antibodies for human CD90, CD 73 and CD 34 (BD Biosciences, San Jose, USA) $(n=2)$. A flow cytometric analysis was performed using a FACSCanto II flow cytometer (BD Biosciences) and FACSDiva software (BD Biosciences).

\section{Total RNA extraction and quantification using RT-PCR}

The cell spheroids were harvested on day 7. Total RNA was isolated using a GeneJET RNA Purification Kit (ThermoFisher Scientific Inc., Waltham, USA), and the quantities were determined with an ND-2000 spectrophotometer (ThermoFisher Scientific Inc.) using ratios of absorbance at $260 \mathrm{~nm}$ and $280 \mathrm{~nm}$. The sense and antisense primers were based on GenBank. The primer sequences were as follows: RUNX2 Forward 5' - AAT GAT GGT GTT GAC GCT GA - 3'; Reverse 5' - TTG ATA CGT GTG GGA TGT GG - 3'; Collagen I Forward 5' - TCA TGG CCC TCC AGC CCC CAT3'; and Reverse 5' - ATG CCT CTT GTC CTT GGG GTT C - 3'. $\beta$-actin served as a housekeeping gene for normalization. The mRNA expression was detected with real-time polymerase chain reaction (RT-PCR) using SYBR Green RealTime PCR Master Mixes (Enzynomics Inc., Daejeon, South Korea) according to the manufacturer's protocol. The quantitative RT-PCR experiments were conducted 3 times.

\section{Alkaline phosphatase activity assays and alizarin red $\mathrm{S}$ staining}

Cell spheroids that had been grown on culture plates with an osteogenic medium were harvested on day 14 . Alkaline phosphatase activity assays were performed with a commercially available kit (BioVision Inc., Milpitas, USA). The cells were suspended again with an assay buffer, sonicated and then centrifuged to remove insoluble material. The supernatant was mixed with a p-nitrophenylphosphate substrate and incubated at $25^{\circ} \mathrm{C}$ for $60 \mathrm{~min}$. The optical density of the resultant p-nitrophenol at $405 \mathrm{~nm}$ was determined spectrophotometrically $(n=3)$.

On days 7 and 14, the spheroids were washed twice with phosphate-buffered saline (PBS) (Welgene, Gyeongsan, South Korea), fixed with $4 \%$ paraformaldehyde and rinsed twice with deionized water. The cultures were then stained with alizarin red S for $30 \mathrm{~min}$ at room temperature. To remove nonspecifically-bound stains, the cultures were washed 3 times with deionized water. A morphological evaluation was then performed using a Leica DM IRM inverted microscope (Leica Camera AG, Wetzlar, Germany) $(n=3)$.

\section{Statistical analysis}

The data is presented as means \pm standard deviations (SD). A test of normality was conducted and a oneway analysis of variance (ANOVA) with a post hoc test were performed to determine the differences between the groups. The analysis was done using SPSS v. 12 software for Windows (SPSS Inc., Chicago, USA), and the level of significance was $\mathrm{p}<0.05$.

\section{Results}

\section{Evaluation of cell morphology and viability}

On day 1 , the spheroids were properly formed in concave silicon elastomer-based microwells (Fig. 1A). The addition of simvastatin caused no significant changes in the morphology on day 1 (Fig. 1B,C). The morphological results for days 3 and 5 are shown in Fig. 1D-I. In general, the shapes of the cells in the experimental groups were similar to those in the control group $(0 \mu \mathrm{M})$.

Using a confocal microscope, the cellular viability was determined using live/dead assays on days 3 and 5, as shown in Fig. 2 and 3, respectively. For day 3, most of the cells in the spheroids emitted green fluorescence and had a round morphology (Fig. 2). Similarly, most of the cells in the spheroids emitted green fluorescence, but an increase in red fluorescence was noted at the higher dose of simvastatin $(10 \mu \mathrm{M})$. The CCK-8 results for days 1 , 3 and 5 are shown in Fig. 4. In terms of quantitative results, no significant changes in cellular viability were noted with the addition of simvastatin on days 1, 3 and 5 .

\section{Secretion of human VEGF from spheroids and expression of stem cell markers}

The results clearly showed that VEGF secretion was observable on the $1^{\text {st }}$ day, and that stable VEGF secretion occurred throughout the culture period (Fig. 5). A decrease in VEGF secretion was noted with the addition of simvastatin $(1 \mu \mathrm{M})$ on day 3 . A statistically significant decrease in secretion was noted with the addition of simvastatin $(1 \mu \mathrm{M}$ and $10 \mu \mathrm{M})$ on day $5(\mathrm{p}<0.05)$.

Expression of the CD90, CD73 and CD34 surface markers was seen on day 7 (Fig. 6). The percentage of CD90 was $89.7 \%$ for the untreated control group $(0 \mu \mathrm{M}), 86.0 \%$ for the $1 \mu \mathrm{M}$ group and $77.1 \%$ for the $10 \mu \mathrm{M}$ group. The percentage of CD73 was $83.5 \%$ for the untreated control group $(0 \mu \mathrm{M}), 82.9 \%$ for the $1 \mu \mathrm{M}$ group and $65.9 \%$ for the $10 \mu \mathrm{M}$ group. The percentage of CD34 was $1.4 \%$ for the untreated control group $(0 \mu \mathrm{M}), 1.1 \%$ for the $1 \mu \mathrm{M}$ group and $3.2 \%$ for the $10 \mu \mathrm{M}$ group. 

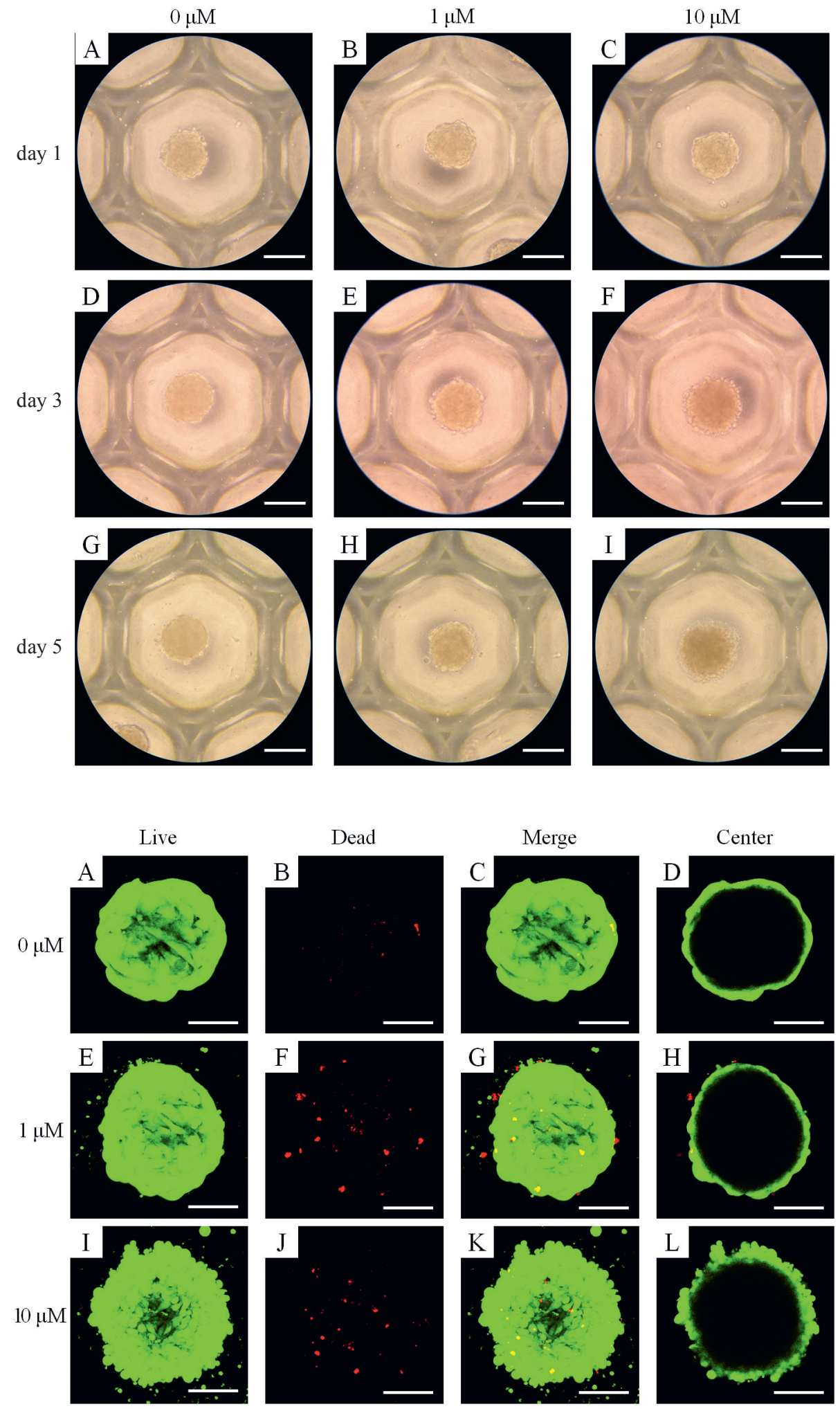

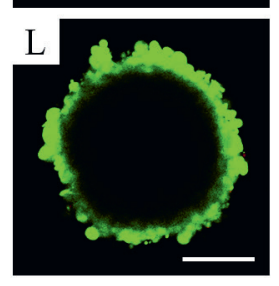

Fig. 1. Morphology of cell spheroids cultured in osteogenic media, the simvastatin $1 \mu \mathrm{M}$ group and the simvastatin $10 \mu \mathrm{M}$ group

(A) Morphology of the cell spheroids on day 1 for the untreated control group (original magnification $\times 200$ )

(B) Morphology of the cell spheroids on day 1 for the simvastatin $1 \mu \mathrm{M}$ group (original magnification $\times 200$ ) (C) Morphology of the cell spheroids on day 1 for the simvastatin $10 \mu \mathrm{M}$ group (original magnification $\times 200$ )

(D) Morphology of the cell spheroids on day 3 for the untreated control group (original magnification $\times 200$ )

(E) Morphology of the cell spheroids on day 3 for the simvastatin $1 \mu \mathrm{M}$ group (original magnification $\times 200$ )

(F) Morphology of the cell spheroids on day 3 for the simvastatin $10 \mu \mathrm{M}$ group (original magnification $\times 200$ )

(G) Morphology of the cell spheroids on day 5 for the untreated control group (original magnification $\times 200$ )

$(\mathrm{H})$ Morphology of the cell spheroids on day 5 for the simvastatin $1 \mu \mathrm{M}$ group (original magnification $\times 200$ )

(I) Morphology of the cell spheroids on day 5 for the simvastatin $10 \mu \mathrm{M}$ group (original magnification $\times 200$ )

The scale bar indicates $200 \mu \mathrm{M}$.

Fig. 2. Qualitative results of cellular viability under a confocal microscope on day 3

(A) Live image of the untreated control group on day 3 (original magnification $\times 100$ ) (B) Dead image of the untreated control group on day 3 (original magnification $\times 100$ ) (C) Merged image of the untreated control group on day 3 (original magnification $\times 100$ ) (D) Central image of the untreated control group on day 3 (original magnification $\times 100$ ) (E) Live image of the simvastatin $1 \mu \mathrm{M}$ group on day 3 (original magnification $\times 100$ )

(F) Dead image of the simvastatin $1 \mu \mathrm{M}$ group on day 3 (original magnification $\times 100$ ) (G) Merged image of the simvastatin $1 \mu \mathrm{M}$ group on day 3 (original magnification $\times 100$ ) $(\mathrm{H})$ Central image of the simvastatin $1 \mu \mathrm{M}$ group on day 3 (original magnification $\times 100$ ) (I) Live image of the simvastatin $10 \mu \mathrm{M}$ group on day 3 (original magnification $\times 100$ ) (J) Dead image of the simvastatin $10 \mu \mathrm{M}$ group on day 3 (original magnification $\times 100$ ) (K) Merged image of the simvastatin $10 \mu \mathrm{M}$ group on day 3 (original magnification $\times 100$ ) (L) Central image of the simvastatin $10 \mu \mathrm{M}$ group on day 3 (original magnification $\times 100$ ) The scale bar indicates $100 \mu \mathrm{M}$

\section{Validation of mRNA expression using RT-PCR}

The quantitative RT-PCR results for the mRNA levels of collagen I and RUNX2 are shown in Fig. 7. The addition of simvastatin produced statistically significant increases in the expression of collagen I and RUNX2. For the untreated control group, the $1 \mu \mathrm{M}$ group and the $10 \mu \mathrm{M}$ group, the relative expressions of collagen I were $100.0 \pm 1.7 \%$, $164.1 \pm 2.4 \%$ and $898.4 \pm 1.2 \%$, respectively ( $\mathrm{p}<0.05$ ), and the relative expressions of RUNX2 were $100.0 \pm 1.2 \%$, $91.5 \pm 0.6 \%$ and $150.1 \pm 0.9 \%$, respectively $(\mathrm{p}<0.05)$. 

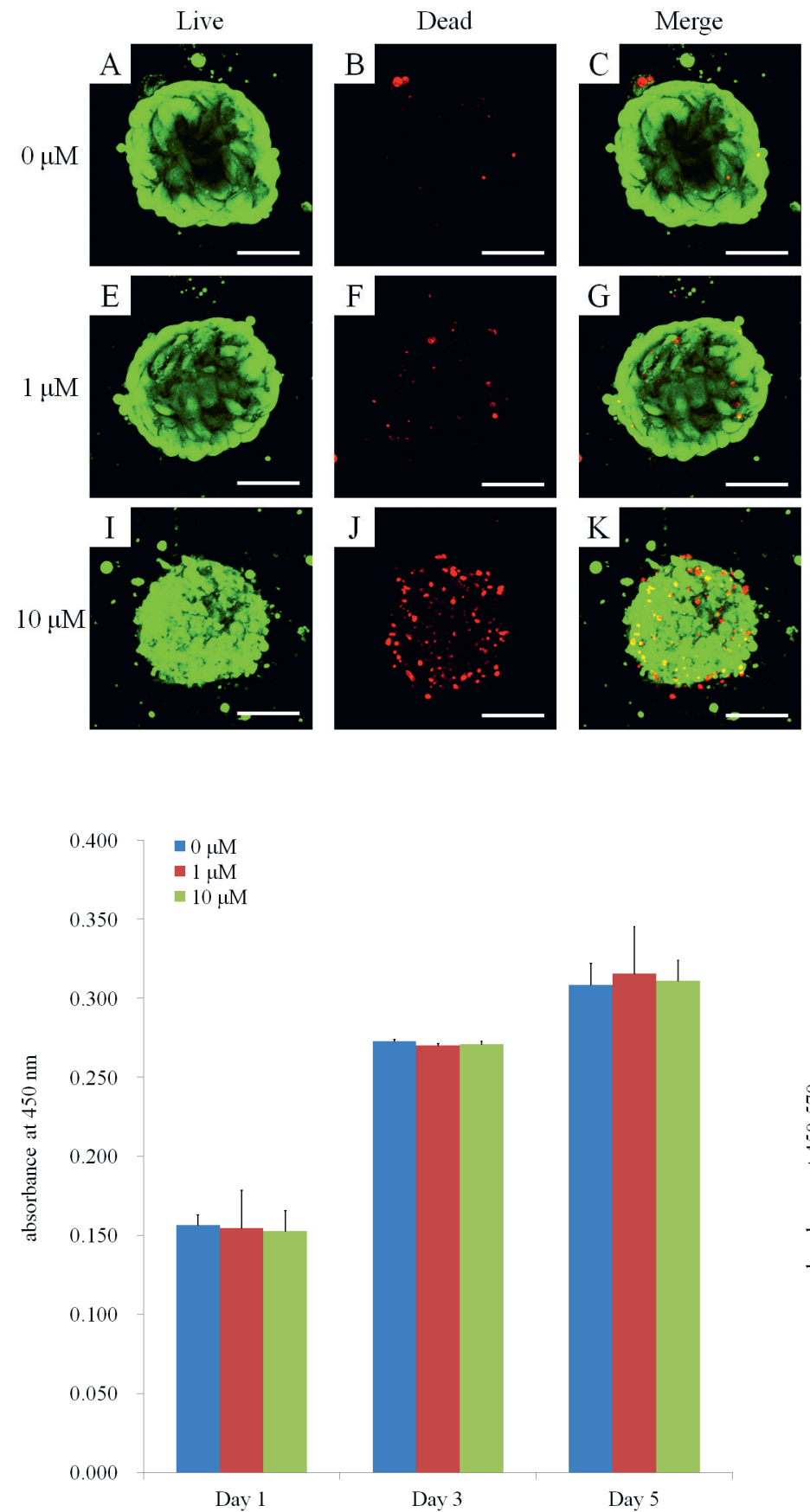

Fig. 4. Cellular viability on days 1, 3 and 5 using CCK-8. No significant changes in cellular viability were noted with the addition of simvastatin on days 1,3 and 5

\section{Alkaline phosphatase activity assays and alizarin red S staining}

Alkaline phosphatase activity decreased on day 14 after treatment with simvastatin, as shown in Fig. 8. The relative values on day 14 for the untreated control group, the $1 \mu \mathrm{M}$ group and the $10 \mu \mathrm{M}$ group were $100.0 \pm 1.6 \%, 49.3 \pm 0.4 \%$ and $25.8 \pm 0.0 \%$, respectively.

Mineralized extracellular deposits were evaluated using alizarin red S staining on days 7 and 14 (Fig. 9) and were found to be equivalent in all 3 groups. An increase
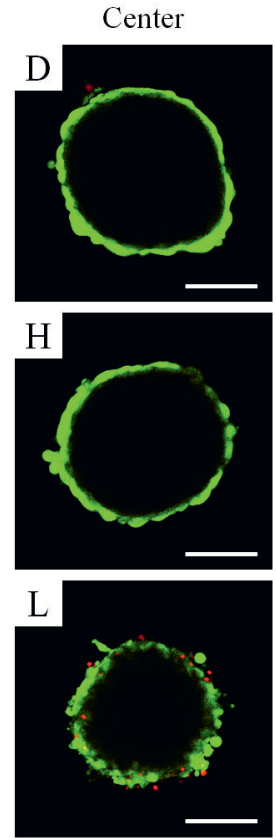

Fig. 3. Qualitative results of cellular viability under a confocal microscope on day 5

(A) Live image of the untreated control group on day 5 (original magnification $\times 100$ ) (B) Dead image of the untreated control group on day 5 (original magnification $\times 100$ ) (C) Merged image of the untreated control group on day 5 (original magnification $\times 100$ ) (D) Central image of the untreated control group on day 5 (original magnification $\times 100$ ) (E) Live image of the simvastatin $1 \mu \mathrm{M}$ group on day 5 (original magnification $\times 100$ )

(F) Dead image of the simvastatin $1 \mu \mathrm{M}$ group on day 5 (original magnification $\times 100$ ) (G) Merged image of the simvastatin $1 \mu \mathrm{M}$ group on day 5 (original magnification $\times 100$ ) $(\mathrm{H})$ Central image of the simvastatin $1 \mu \mathrm{M}$ group on day 5 (original magnification $\times 100$ ) (I) Live image of the simvastatin $10 \mu \mathrm{M}$ group on day 5 (original magnification $\times 100$ ) (J) Dead image of the simvastatin $10 \mu \mathrm{M}$ group on day 5 (original magnification $\times 100$ ) (K) Merged image of the simvastatin $10 \mu \mathrm{M}$ group on day 5 (original magnification $\times 100$ ) $(\mathrm{L})$ Central image of the simvastatin $10 \mu \mathrm{M}$ group on day 5 (original magnification $\times 100$ ) The scale bar indicates $100 \mu \mathrm{M}$.

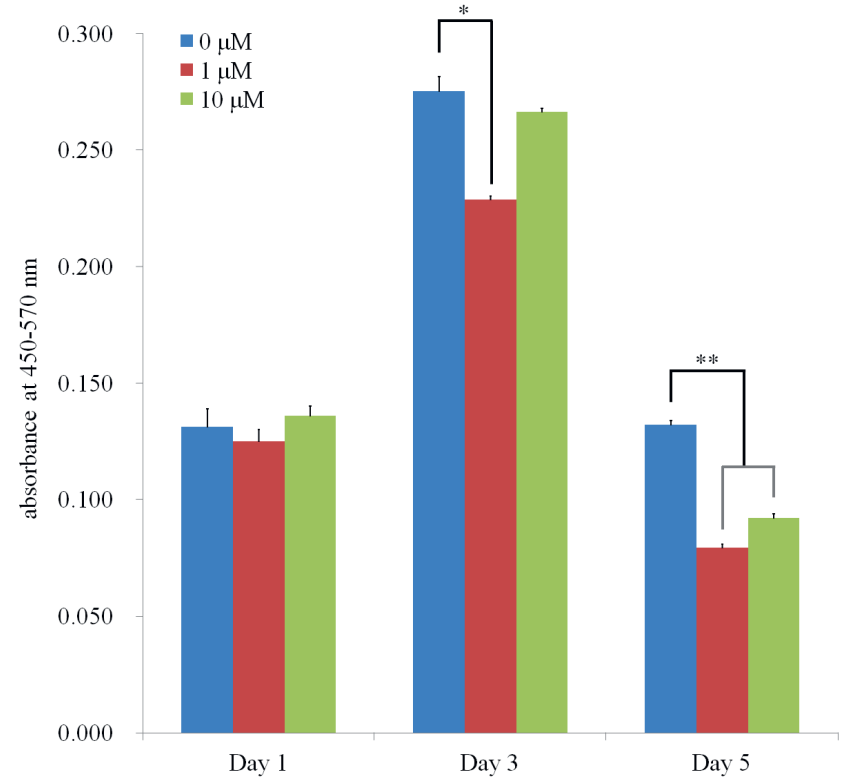

Fig. 5. Secretion of VEGFs from cell spheroids on days 1, 3 and 5. A decrease in VEGF secretion was noted with the addition of simvastatin $(1 \mu \mathrm{M})$ on day 3 . A statistically significant decrease in secretion was noted with the addition of simvastatin $(1 \mu \mathrm{M}$ and $10 \mu \mathrm{M})$ on day 5

in mineralized deposits was noted between day 7 and day 14. Alizarin red S staining decreased with the addition of simvastatin.

\section{Discussion}

This report discusses the effects of simvastatin on cellular viability, stemness and osteogenic differentiation using 3-dimensional cell spheroids of stem cells and osteoblastlike cells. The addition of simvastatin clearly enhanced 

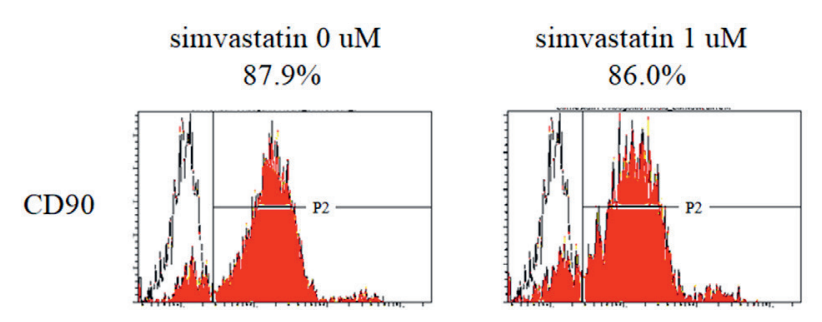

$83.5 \%$

$\mathrm{CD} 3$

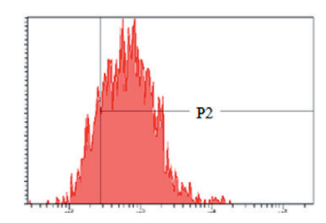

$1.4 \%$
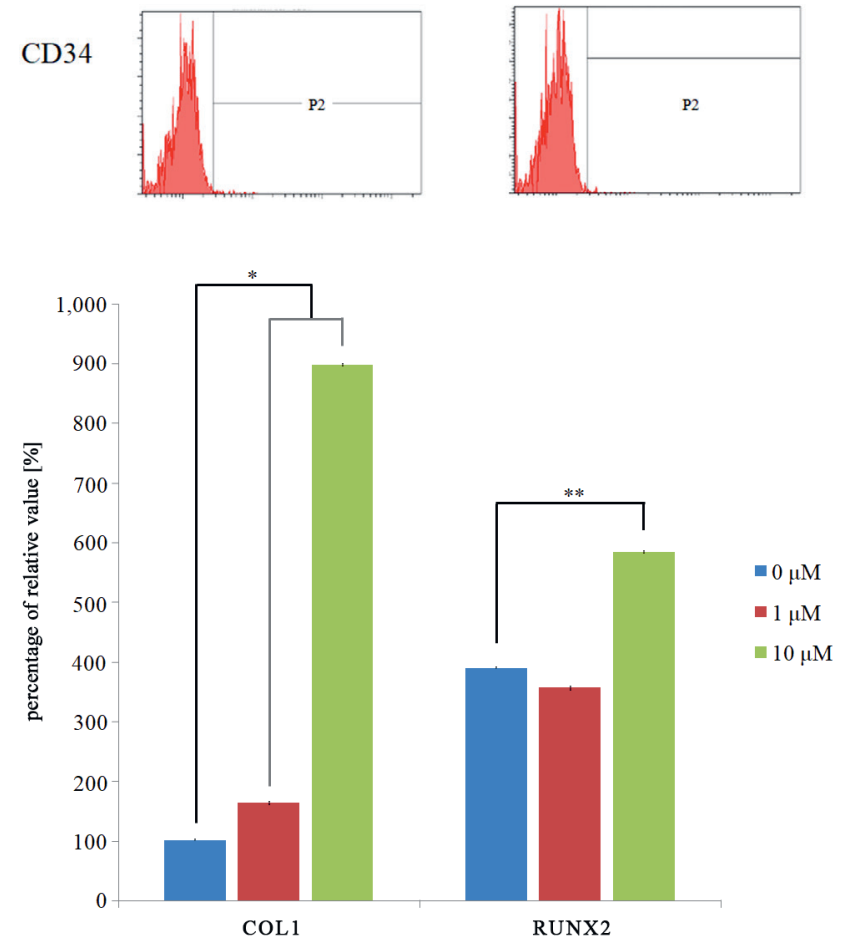

Fig. 7. Quantitative real-time polymerase chain reaction results for collagen I and RUNX2 expression on day 7. The addition of simvastatin produced statistically significant increases in the expression of collagen I and RUNX2. For the untreated control group, the $1 \mu \mathrm{M}$ group, and the $10 \mu \mathrm{M}$ group, the relative expressions of collagen I are $100.0 \pm 1.7 \%$, $164.1 \pm 2.4 \%$ and $898.4 \pm 1.2 \%$, respectively, and the relative expressions of RUNX2 are $100.0 \pm 1.2 \%, 91.5 \pm 0.6 \%$ and $150.1 \pm 0.9 \%$, respectively

collagen I and RUNX2 expression, but it did not lead to increased alkaline phosphatase activity or increased alizarin red S staining.

Simvastatin has been shown to increase therapeutic effects by enhancing stem cell function. ${ }^{8}$ Simvastatin induces increased pluripotency and protects against cellular senescence in MSCs. ${ }^{6}$ It also improves the migration of bone marrow-derived MSCs via the PI3K/AKT pathway, ${ }^{14}$ and enhances the neurogenesis of cultured neural stem cells and elevates Notch-1 protein expression. ${ }^{7}$ Simvastatin simvastatin $10 \mathrm{uM}$ $77.1 \%$

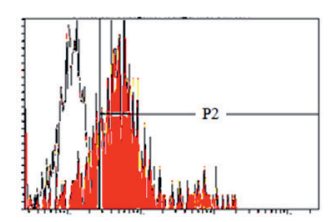

$65.9 \%$

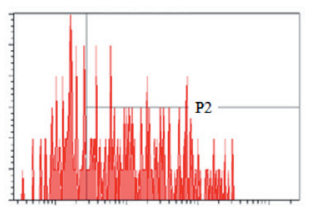

$3.2 \%$

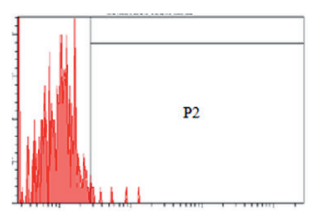

Fig. 6. Evaluation of stem cell surface marker expression using CD90, CD73 and CD34 on day 7. The percentage of CD90 was $89.7 \%$ for the untreated control group $(0 \mu \mathrm{M}), 86.0 \%$ for the $1 \mu \mathrm{M}$ group and $77.1 \%$ for the $10 \mu \mathrm{M}$ group. The percentage of CD73 was $83.5 \%$ for the untreated control group $(0 \mu \mathrm{M}), 82.9 \%$ for the $1 \mu \mathrm{M}$ group and $65.9 \%$ for the $10 \mu \mathrm{M}$ group. The percentage of CD34 was 1.4\% for the untreated control group $(0 \mu \mathrm{M}), 1.1 \%$ for the $1 \mu \mathrm{M}$ group and 3.2\% for the $10 \mu \mathrm{M}$ group

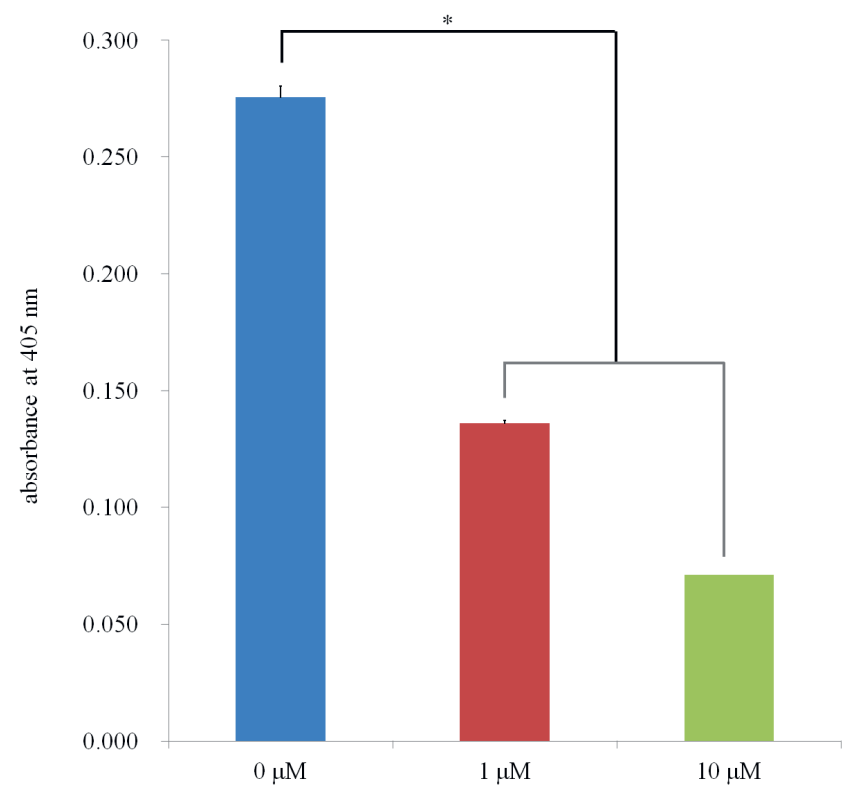

Fig. 8. Alkaline phosphatase activity on day 14. The relative values on day 14 for the untreated control group, the $1 \mu \mathrm{M}$ group and the $10 \mu \mathrm{M}$ group are $100.0 \pm 1.6 \%, 49.3 \pm 0.4 \%$ and $25.8 \pm 0.0 \%$, respectively

exhibits increased dentin sialoprotein and calcium deposition, and it has been suggested that it can promote odontoblastic differentiation in dental pulp stem cells. ${ }^{15}$ Moreover, previous reports have shown that simvastatin stimulates osteogenic effects in bone marrow-derived MSCs. ${ }^{16}$ It has also been shown that it enhances the osteogenic differentiation of stem cells without affecting their immunosuppressive properties. ${ }^{17}$ Additionally, simvastatin increases bone morphogenetic protein-2 gene expression on titanium surfaces that have been sandblasted with large 
$0 \mu \mathrm{M}$

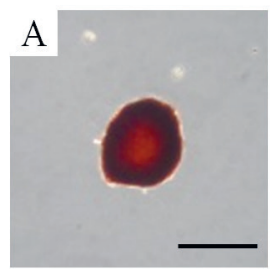

day 14

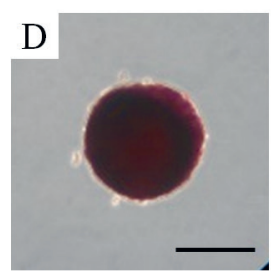

$1 \mu \mathrm{M}$
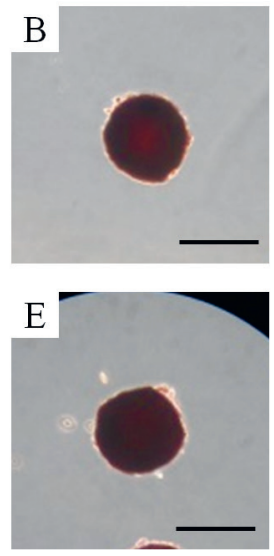

$10 \mu \mathrm{M}$
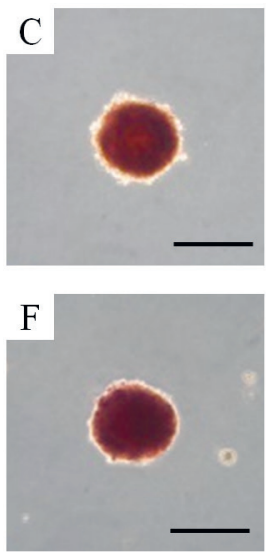

Fig. 9. Mineralization assay using alizarin red S staining

(A) Alizarin red S staining results on day 7 for the untreated control group (original magnification $\times 200$ )

(B) Alizarin red S staining results on day 7 for the simvastatin $1 \mu \mathrm{M}$ group (original magnification $\times 200$ )

(C) Alizarin red S staining results on day 7 for the simvastatin $10 \mu \mathrm{M}$ group (original magnification $\times 200$ )

(D) Alizarin red S staining results on day 14 for the untreated control group (original magnification $\times 200$ )

(E) Alizarin red S staining results on day 14 for the simvastatin $1 \mu \mathrm{M}$ group (original magnification $\times 200$ )

(F) Alizarin red S staining results on day 14 for the simvastatin $10 \mu \mathrm{M}$ group (original magnification $\times 200$ )

The scale bar indicates $100 \mu \mathrm{M}$. grit and etched with acid. ${ }^{18}$ To add to these observations, the present study showed that simvastatin enhanced collagen I and RUNX2 expression.

This report discusses the effects that simvastatin has on the viability and differentiation of cells at predetermined concentrations $(1 \mu \mathrm{M}$ and $10 \mu \mathrm{M})$. Previous studies have shown that simvastatin at concentrations of $0.1 \mu \mathrm{M}$ and $1 \mu \mathrm{M}$ can be used for the differentiation of osteoblastlike cells ${ }^{4}$. In another report, $0.01 \mu \mathrm{M}$ and $0.1 \mu \mathrm{M}$ concentrations of simvastatin were used for the osteoblastic differentiation of osteoblast-like cells. ${ }^{19}$ In a previous report, $1 \mu \mathrm{M}$ concentration of simvastatin was applied to bone marrow-derived $\mathrm{MSCs}^{17}$; simvastatin significantly decreased the proliferation of the MSCs and notably enhanced osteogenic differentiation. ${ }^{20}$ The present study clearly proved that at $1 \mu \mathrm{M}$ and $10 \mu \mathrm{M}$ concentration, simvastatin had significant effects on a 3-dimensional culture model. Variations in doses could be used to achieve optimal effects based on the culture system, the duration of the culture period and the type of cells. ${ }^{4,19}$

Various scaffolds have been utilized for simvastatin use. ${ }^{15,21-24}$ A hydrogel composed of gelatin-poly(ethylene glycol)-tyramine has been used as an efficient simvastatin delivery vehicle to trigger osteogenic differentiation. ${ }^{21}$ Calcium phosphate composite scaffolds containing simvastatin-loaded poly(lactic-co-glycolic acid) microspheres have been fabricated, and MSCs have been seeded onto the scaffolds. ${ }^{22}$ Simvastatin has been incorporated into the micelles of gelatin grafted with L-lactic acid oligomers, and enhanced alkaline phosphatase activity was achieved. ${ }^{15}$ Simvastatin has been incorporated into mesoporous hydroxyapatite microspheres; this system led to superior bone regeneration from sustained release. ${ }^{23}$ It has also been incorporated into hydroxyapatite in poly( $\varepsilon$-caprolactone)/polylactic acid polymeric scaffolds for osteogenic bioengineering. ${ }^{24}$

Simvastatin-stimulated osteogenesis is mediated by estrogen receptor $\alpha .{ }^{16}$ It has also been noted that simvastatin enhances the Rho/actin/cell rigidity pathway, contributing to osteogenic differentiation of MSCs; both keeping the actin cytoskeletons intact and enhancing cell rigidity is crucial in simvastatin-induced osteogenesis. ${ }^{25}$ The current study added the observation that simvastatin was involved with the RUNX2 pathway.

In this study, cell viability was evaluated using a CCK-8 assay. CCK- 8 is based on mitochondrial enzyme activity and quantification of the formazan generated. ${ }^{12,26}$ Alkaline phosphatase activity is used as an early marker of osteogenesis. ${ }^{27}$ Alizarin red S staining is used to evaluate the quantity of calcium deposits after matrix maturation. ${ }^{28}$ There may be limitations for applying these assays to spheroid cultures because they were initially dedicated for 2-dimensional cultures.

This study clearly showed that the application of simvastatin enhances collagen I and RUNX2 expression but does not lead to increased alkaline phosphatase activity or increased alizarin red S staining.

\section{References}

1. Park JB. The use of simvastatin in bone regeneration. Med Oral Patol Oral Cir Bucal. 2009;14(9):e485-488.

2. Zhang $\mathrm{H}$, Wang $\mathrm{L}$, Park JB, et al. Intradiscal injection of simvastatin retards progression of intervertebral disc degeneration induced by stab injury. Arthritis Res Ther. 2009;11(6):R172.

3. Park JB. Combined effects of simvastatin and fibroblast growth factor-2 on the proliferation and differentiation of preosteoblasts. Biomed Rep. 2013;1(5):812-814.

4. Park JB, Zhang H, Lin CY, et al. Simvastatin maintains osteoblastic viability while promoting differentiation by partially regulating the expressions of estrogen receptors alpha. J Surg Res. 2012;174(2): 278-283.

5. Park JB. Combination of simvastatin and bone morphogenetic protein-2 enhances the differentiation of osteoblasts by regulating the expression of phospho-Smad1/5/8. Exp Ther Med. 2012;4(2): 303-306.

6. Zanette DL, Lorenzi JC, Panepucci RA, et al. Simvastatin modulates mesenchymal stromal cell proliferation and gene expression. PLoS One. 2015;10(4):e0120137.

7. Xie $C$, Cong $D$, Wang $X$, et al. The effect of simvastatin treatment on proliferation and differentiation of neural stem cells after traumatic brain injury. Brain Res. 2015;1602:1-8.

8. Huang Z, Zhang L, Feng X, Chen T, Bi S. A new in vivo method to retard progression of intervertebral disc degeneration through stimulation of endogenous stem cells with simvastatin. Med Hypotheses. 2017;101: 65-66. 
9. Mendes Jr D, Domingues JA, Hausen MA, et al. Study of mesenchymal stem cells cultured on a poly(lactic-co-glycolic acid) scaffold containing simvastatin for bone healing. J Appl Biomater Funct Mater. 2017;15(2):e133-e141.

10. Lee SI, Yeo SI, Kim BB, Ko Y, Park JB. Formation of size-controllable spheroids using gingiva-derived stem cells and concave microwells: Morphology and viability tests. Biomed Rep. 2016;4(1):97-101.

11. Lee SI, Ko Y, Park JB. Evaluation of the maintenance of stemness, viability, and differentiation potential of gingiva-derived stem-cell spheroids. Exp Ther Med. 2017;13(5):1757-1764.

12. Lee SI, Ko Y, Park JB. Evaluation of the shape, viability, stemness and osteogenic differentiation of cell spheroids formed from human gingiva-derived stem cells and osteoprecursor cells. Exp Ther Med.2017; 13(6):3467-3473.

13. Jin SH, Lee JE, Yun JH, Kim I, Ko Y, Park JB. Isolation and characterization of human mesenchymal stem cells from gingival connective tissue. J Periodontal Res. 2015;50(4):461-467.

14. Bing W, Pang $X, Q u$ Q, et al. Simvastatin improves the homing of BMSCs via the PI3K/AKT/miR-9 pathway. J Cell Mol Med. 2016;20(5):949-961.

15. Miyazawa A, Matsuno T, Asano K, Tabata Y, Satoh T. Controlled release of simvastatin from biodegradable hydrogels promotes odontoblastic differentiation. Dent Mater J. 2015;34(4):466-474.

16. Chuang SC, Chen $\mathrm{CH}, \mathrm{Fu} Y \mathrm{YC}$, et al. Estrogen receptor mediates simvastatin-stimulated osteogenic effects in bone marrow mesenchymal stem cells. Biochem Pharmacol. 2015;98(3):453-464.

17. Niu J, Ding G, Zhang L. Effects of simvastatin on the osteogenic differentiation and immunomodulation of bone marrow mesenchymal stem cells. Mol Med Rep. 2015;12(6):8237-8240.

18. Arpornmaeklong P, Pripatnanont P, Chookiatsiri C, Tangtrakulwanich $B$. Effects of titanium surface microtopography and simvastatin on growth and osteogenic differentiation of human mesenchymal stem cells in estrogen-deprived cell culture. Int J Oral Maxillofac Implants. 2017;32(1):e35-e46.
19. Maeda T, Matsunuma A, Kawane T, Horiuchi N. Simvastatin promotes osteoblast differentiation and mineralization in MC3T3-E1 cells. Biochem Biophys Res Commun. 2001;280(3):874-877.

20. Baek KH, Lee WY, Oh KW, et al. The effect of simvastatin on the proliferation and differentiation of human bone marrow stromal cells. J Korean Med Sci. 2005;20(3):438-444.

21. Park YS, David AE, Park KM, et al. Controlled release of simvastatin from in situ forming hydrogel triggers bone formation in MC3T3-E1 cells. AAPS J. 2013;15(2):367-376.

22. Zhang HX, Xiao GY, Wang $X$, et al. Biocompatibility and osteogenesis of calcium phosphate composite scaffolds containing simvastatinloaded PLGA microspheres for bone tissue engineering. J Biomed Mater Res A. 2015;103(10):3250-3258.

23. Yu WL, Sun TW, Qi C, et al. Enhanced osteogenesis and angiogenesis by mesoporous hydroxyapatite microspheres-derived simvastatin sustained release system for superior bone regeneration. Sci Rep. 2017;7:44129.

24. Samiei M, Aghazadeh M, Alizadeh E, et al. Osteogenic/odontogenic bioengineering with co-administration of simvastatin and hydroxyapatite on poly caprolactone based nanofibrous scaffold. Adv Pharm Bull. 2016;6(3):353-365.

25. Tai IC, Wang YH, Chen CH, Chuang SC, Chang JK, Ho ML. Simvastatin enhances Rho/actin/cell rigidity pathway contributing to mesenchymal stem cells' osteogenic differentiation. Int J Nanomedicine. 2015;10:5881-5894.

26. Jeong SH, Kim BB, Lee JE, Ko Y, Park JB. Evaluation of the effects of Angelicae dahuricae radix on the morphology and viability of mesenchymal stem cells. Mol Med Rep. 2015;12(1):1556-1560.

27. Park JB. Low dose of doxycycline promotes early differentiation of preosteoblasts by partially regulating the expression of estrogen receptors. J Surg Res. 2012;178(2):737-742.

28. Park JB. The effects of dexamethasone, ascorbic acid, and beta-glycerophosphate on osteoblastic differentiation by regulating estrogen receptor and osteopontin expression. J Surg Res. 2012;173(1):99-104. 